\title{
Prolactin regulates LAT1 expression via STAT5 (signal transducer and activator of transcription 5) signaling in mammary epithelial cells of dairy cows
}

\author{
Jinyu Zhou, ${ }^{1} \oplus$ Minghui Jiang, ${ }^{2} \oplus$ Ying Shi, ${ }^{1} \oplus$ Shuyuan Song, ${ }^{2} \oplus$ Xiaoming Hou, ${ }^{2} \odot$ and Ye Lin ${ }^{1 *} \oplus$ \\ ${ }^{1}$ Key Laboratory of Dairy Science of Education Ministry, Northeast Agricultural University, Harbin 150030, China \\ ${ }^{2}$ Key Laboratory of Animal Cellular and Genetics Engineering of Heilongjiang Province, Northeast Agricultural University, Harbin 150030, China
}

\section{ABSTRACT}

The L-type amino acid transporter 1 (LAT1; also known as SLC7A5) is a transporter that allows the uptake of large neutral amino acids into mammalian cells. In dairy cows, LAT1 is highly expressed in lactating mammary tissues and involved in milk protein synthesis. Prolactin (PRL) has a lactogenic role and is capable of inducing milk production in ruminants. However, the relationship between PRL stimulation and LAT1 expression in dairy cow mammary gland has not been well understood. In this study, we showed that PRL stimulation increased expression of LAT1 and $\beta$-casein in mammary epithelial cells of dairy cows. The stimulatory effect of PRL on milk protein production was inhibited by LAT1-specific inhibitor or LAT1 knockdown, suggesting that PRL-induced milk protein production is involved in LAT1 expression. To determine whether the PRL signaling pathway participates in regulation of LAT1 expression, PRLR (PRL receptor) or STAT5 (signal transducer and activator of transcription 5) was knocked down by short interfering (si)RNA in mammary epithelial cells of dairy cows. Western blot results showed that knockdown of PRLR or STAT5 with siRNA markedly decreased PRL-stimulated LAT1 expression. In addition, we observed a marked increase in plasma membrane expression of LAT1 in PRL-stimulated cells compared with control cells. These observations indicated that PRL signaling can regulate LAT1 expression and activity in mammary epithelial cells of dairy cows, contributing to increased amino acid availability and milk protein synthesis in mammary gland of dairy cow. Key words: mammary epithelial cell, prolactin, LAT1 (L-type amino acid transporter 1), milk protein

Received November 22, 2019

Accepted March 7, 2020.

*Corresponding author: linlu516@163.com

\section{INTRODUCTION}

Amino acids are essential nutrients for protein synthesis and other metabolic functions. The L-type amino acid transporter 1 (LAT1, also known as SLC7A5) is important for the transport of neutral amino acids, including nutritionally essential AA (Christensen, 1990). The L-type amino acid transporter 1 is part of the SLC7 family and forms a heterodimer with the heavy chain of 4F2 (4F2hc, also known as SLC3A2) via a disulfide bond on the cell surface (Mastroberardino et al., 1998; Napolitano et al., 2015). When expressed in mammalian cells together with 4F2hc, LAT1 induces the transport of neutral AA from the circulation into cells (Nakamura et al., 1999).

The L-type amino acid transporter 1 is highly expressed in many tissues, including the blood-brain barrier, placenta, and skeletal muscle, and it provides EAA for the high-level synthesis of proteins (Boado et al., 1999; Drummond et al., 2010; Rosario et al., 2013). It is also expressed in lactating mammary tissues of dairy cows (Finucane et al., 2008; Lin et al., 2018). Knockdown of LAT1 in cultured bovine mammary epithelial cells significantly decreases cell viability and $\beta$-casein expression, suggesting that it provides the EAA needed for milk protein synthesis (Lin et al., 2018).

Prolactin (PRL) is known as a galactopoietic hormone and is capable of inducing milk production (Lacasse et al., 2016). The galactopoietic role of PRL has been well established in rodents (Neville et al., 2002). In dairy cows, PRL content increases in blood plasma around parturition (Edgerton and Hafs, 1973). In cultured bovine mammary epithelial cells, PRL upregulates CSN mRNA expression (Choi et al., 1988). The long-term inhibition of PRL reduces milk yield in dairy cows, indicating its galactopoietic role in ruminants (Lacasse et al., 2011; Lollivier et al., 2015). Although PRL signaling has been extensively studied in milk protein synthesis during lactation, less information is available to describe the relationship between AA 
transport and PRL signaling, especially in mammary glands of dairy cows.

In this study, we hypothesized that PRL regulates LAT1 expression and activity in mammary epithelial cells of dairy cows. To test this hypothesis, we evaluated the effects of different concentrations of PRL on LAT1 expression in mammary epithelial cells of dairy cows. Then, using a specific inhibitor and gene knockdown, we determined whether PRL signaling regulates LAT1 expression, thereby controlling milk protein synthesis.

\section{MATERIALS AND METHODS}

\section{Cell Culture and Treatment}

Mammary epithelial cells were prepared from mammary parenchymal tissues of 3 lactating Holstein cows as described previously (Lin et al., 2018). All procedures involving animals were in accordance with institutional guidelines and were approved by the Northeast Agricultural University Animal Care and Use Committee (2019-2, Harbin, China). The 3 cows were in their third parity and at 90 DIM. All cows were in good health and had SCC $<50,000$ cells/mL. Mammary epithelial cells were isolated by collagenase digestion. Briefly, the mammary tissues were minced with surgical scissors and digested for $2 \mathrm{~h}$ at $37^{\circ} \mathrm{C}$ with $1 \mathrm{mg} / \mathrm{mL}$ collagenase III (Solarbio, Beijing, China). Then, the digest was filtered through a nylon mesh and the filtrate was centrifuged at $150 \times g$ for $10 \mathrm{~min}$. The cell pellet was resuspended and plated on plastic cell culture dishes coated with rat tail collagen (0.5\%; Sigma-Aldrich Inc., St. Louis, MO) and incubated in Dulbecco's modified Eagle's medium/ Nutrient Mixture F-12 medium (DMEM/F12, Life Technologies, Carlsbad, CA) containing 10\% (vol/vol) fetal bovine serum (Life Technologies), $100 \mathrm{U} / \mathrm{mL}$ penicillin, $100 \mu \mathrm{g} / \mathrm{mL}$ streptomycin, $5 \mu \mathrm{g} / \mathrm{mL}$ insulin, and $1 \mu \mathrm{g} / \mathrm{mL}$ hydrocortisone (Sigma-Aldrich). The primary cells were trypsinized at $\sim 80 \%$ confluency with trypsinEDTA $(0.25 \%$, Life Technologies) and passaged. Expression of cytokeratin 18 and $\beta$-casein was detected by immunofluorescence as described (Lin et al., 2018) before each experiment to ensure that the cells were purified mammary epithelial cells and capable of lactation. All experiments were conducted using cells within 10 passages.

To detect the effects of different concentrations of PRL on LAT1 and 4F2hc expression, mammary epithelial cells were plated at $1 \times 10^{6}$ cells/well in 6 -well culture plates. When cells grew to $90 \%$ confluence, the medium was changed to DMEM/F12 with $0,1,2.5$, 5,10 , or $20 \mu \mathrm{g} / \mathrm{mL}$ of PRL. After $24 \mathrm{~h}$ of treatment, cells in triplicate wells were collected for total RNA and protein extraction.
To investigate whether LAT1 was involved in PRLstimulated milk protein synthesis, mammary epithelial cells were grown in 6 -well plates $\left(1 \times 10^{6}\right.$ cells/well $)$ to $90 \%$ confluence. Then cells were treated for $24 \mathrm{~h}$ with $5 \mu \mathrm{g} / \mathrm{mL}$ PRL plus $2.5 \mathrm{~m} M$ 2-amino-2-norbornanecarboxylic acid (BCH, an inhibitor of LAT1; Cayman Chemical, Ann Arbor, MI) or $0.02 \%$ dimethyl sulfoxide (DMSO) as a control.

To investigate the effect of PRL on plasma membrane expression of LAT1, mammary epithelial cells were grown in 6 -well plates $\left(1 \times 10^{6}\right.$ cells/well $)$ to $90 \%$ confluence. Then, the cells were treated with $5 \mu \mathrm{g} / \mathrm{mL}$ PRL for $24 \mathrm{~h}$.

\section{RNA Isolation and Quantitative Real-Time PCR}

Sample preparation and quantification of mRNA abundance was carried out as described (Yang et al., 2017). Briefly, total RNA was extracted from each sample using TRIzol reagent (Life Technologies), and RNA concentrations were measured using a NanoDrop 2000c spectrophotometer (NanoDrop Technologies, Wilmington, DE). Reverse transcription was performed with a PrimeScript Reagent Kit with gDNA Eraser (Takara, Dalian, China). The quantitative real-time PCR (qPCR) was performed using ChamQ Universal SYBR qPCR Master Mix (Vazyme, Nanjing, China) in a Roche LightCycler 96 real-time PCR system (Roche Diagnostics GmbH, Mannheim, Germany). Primers for LAT1 and reference genes were designed with Primer Premier 5.0 software (Premier Biosoft, Palo Alto, CA) and are shown in Table 1 . The qPCR was performed in a $20-\mu \mathrm{L}$ volume containing $10 \mu \mathrm{L}$ of $2 \times$ ChamQ Universal SYBR qPCR Master Mix, $0.4 \mu \mathrm{L}$ each of $10 \mu M$ primers, $1 \mu \mathrm{L}$ of cDNA, and $8.2 \mu \mathrm{L}$ of DNase-/RNasefree water. The amplification program consisted of 1 cycle of $95^{\circ} \mathrm{C}$ for $30 \mathrm{~s}$ and 40 cycles of $95^{\circ} \mathrm{C}$ for $10 \mathrm{~s}$ and $60^{\circ} \mathrm{C}$ for $30 \mathrm{~s}$, followed by an additional cycle of $95^{\circ} \mathrm{C}$ for $15 \mathrm{~s}, 60^{\circ} \mathrm{C}$ for $1 \mathrm{~min}$, and $95^{\circ} \mathrm{C}$ for $15 \mathrm{~s}$ to generate a melting curve. The $\mathrm{qPCR}$ reactions on each sample were performed in triplicate. Expression of LAT1 was normalized using the geometric mean of 3 endogenous genes, ACTB, RPS9, and UXT. The relative RNA expression levels were calculated by the $2^{-\Delta \Delta \mathrm{CT}}$ method (Schmittgen and Livak, 2008).

\section{Transfection}

Short interfering (si)RNAs against the long isoforms of PRLR, LAT1, and STAT5 were purchased from GenePharma (Shanghai, China). Corresponding scrambled siRNAs purchased from GenePharma were used as negative controls. Transient transfection was performed in cultured mammary epithelial cells of dairy 
cows using Lipofectamine 3000 reagent (Life Technologies) as described (Lin et al., 2018). For knockdown of the target gene expression, cells in 6 -well plates $(1 \times$ $10^{6}$ cells/well) were transfected with specific siRNAs in the presence of $5 \mu \mathrm{g} / \mathrm{mL}$ PRL. At $24 \mathrm{~h}$ after transfection, cells were harvested for protein extraction and Western blot analysis. All experiments were performed in triplicate.

\section{Western Blot Analysis}

For Western blot analysis, total proteins were extracted from mammary epithelial cells using RIPA buffer (Beyotime, Shanghai, China) containing 0.5 $\mathrm{m} M$ phenylmethylsulfonyl fluoride (Beyotime), $5 \mathrm{\mu g} /$ $\mathrm{mL}$ aprotinin (Sigma-Aldrich), and $5 \mu \mathrm{g} / \mathrm{mL}$ leupeptin (Sigma-Aldrich). Plasma membrane proteins and cytosol proteins were extracted with a membrane and cytosol protein extraction kit (Beyotime). Protein concentrations were determined by the bicinchoninic acid method. Then, $\sim 40 \mu \mathrm{g}$ of protein was resolved by 10\% SDS-PAGE and transferred to nitrocellulose membranes. Membranes were incubated overnight at $4^{\circ} \mathrm{C}$ with antibodies against LAT1 (1:1,000 dilution; Cell Signaling Technology, Danvers, MA), 4F2hc (1:500 dilution; Proteintech Group Inc., Rosemont, IL), $\beta$-casein (1:500 dilution, Bioss Antibodies, Beijing, China), PRLR (1:1,000 dilution; Cell Signaling Technology), STAT5 (1:1,000 dilution; Cell Signaling Technology), phosphorylated (p)-STAT5 (1:1,000 dilution; Cell Signaling Technology), $\beta$-actin (1:1,000 dilution; Cell Signaling Technology), or $\mathrm{Na}^{+}$-K-ATPase $(1: 100,000$ dilution; Abcam, Cambridge, MA). After washing with Tris-buffered saline-Tween, the membranes were incubated with horseradish peroxidase-conjugated antirabbit IgG (1:500 dilution; ZSGB-BIO, Beijing, China) at room temperature for $1 \mathrm{~h}$. The protein bands were detected using enhanced chemiluminescence detection system (Cell Signaling Technology) and analyzed using Image-Pro Plus 6.0 software (Media Cybernetics,
Warrendale, PA). The target protein expression in cell lysate and cytosol was normalized to expression of $\beta$-actin. Expression of LAT1 in plasma membrane was normalized to that of $\mathrm{Na}^{+}-\mathrm{K}$-ATPase.

\section{Statistical Analysis}

Results are presented as means \pm standard errors of the means (SEM). Data from 3 independent experiments were subjected to statistical analysis. All statistical tests were performed using GraphPad Prism 6 software (GraphPad, La Jolla, CA). To analyze the effects of different concentrations of PRL on LAT1 and $4 \mathrm{~F} 2 \mathrm{hc}$ expression, ANOVA was performed to evaluate differences among the groups. Bonferroni's multiple comparison test was used for post-ANOVA comparisons. To analyze the effects of PRL, BCH, or gene knockdown on STAT5 signaling molecules and LAT1 and CSN2 expression, a 2-tailed unpaired $t$-test was used to compare means between the PRL and $\mathrm{BCH}$ treatment groups or between the gene knockdown group and control group. Differences were considered significant at $P<0.05$.

\section{RESULTS}

\section{PRL Regulates LAT1 Expression and $\beta$-Casein Synthesis in Mammary Epithelial Cells}

To investigate whether PRL can affect LAT1 expression, mammary epithelial cells were cultured in DMEM/F12 with PRL at concentrations ranging from 0 to $20 \mu \mathrm{g} / \mathrm{mL}$. The qPCR results showed that the abundance of LAT1 mRNA was upregulated gradually and peaked at $5 \mu \mathrm{g} / \mathrm{mL}$ PRL (Figure 1A). Western blot analyses also showed that levels of LAT1 and 4F2hc were highest in the medium with $5 \mu \mathrm{g} / \mathrm{mL}$ PRL (Figure $1 \mathrm{~B}, \mathrm{C}, \mathrm{D})$.

To determine whether LAT1 expression and milk protein synthesis were directly regulated by PRL

Table 1. Primer sequences used for quantitative real-time $\mathrm{PCR}^{1}$

\begin{tabular}{|c|c|c|c|}
\hline Gene & GenBank accession number & Primer sequence $\left(5^{\prime}\right.$ to $\left.3^{\prime}\right)$ & Product size (bp) \\
\hline$R P S 9$ & NM_001101152.2 & $\begin{array}{l}\text { F: GCTGATCGGCGAGTATGGG } \\
\text { R: GGGCAGCCTTTCGGATCTT }\end{array}$ & 83 \\
\hline$U X T$ & NM_001037471.2 & $\begin{array}{l}\text { F: GATCTATGTGGCCCTTGGAT } \\
\text { R: CTTGGTGAGGTTGTCGCTG }\end{array}$ & 115 \\
\hline
\end{tabular}

${ }^{1} L A T 1=$ L-type amino acid transporter 1 , encoded by $S L C 7 A 5$, the solute carrier family 7 member 5 gene; $A C T B=\beta$-actin; $R P S 9=$ ribosomal protein $\mathrm{S} 9 ; U X T=$ ubiquitously expressed prefoldin like chaperone; $\mathrm{F}=$ forward $; \mathrm{R}=$ reverse. 


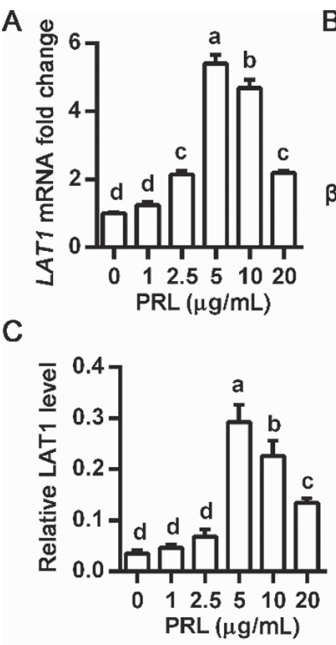

E

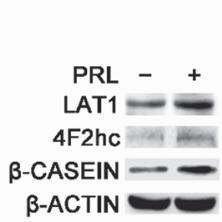

B

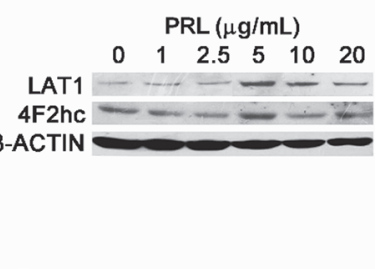

D
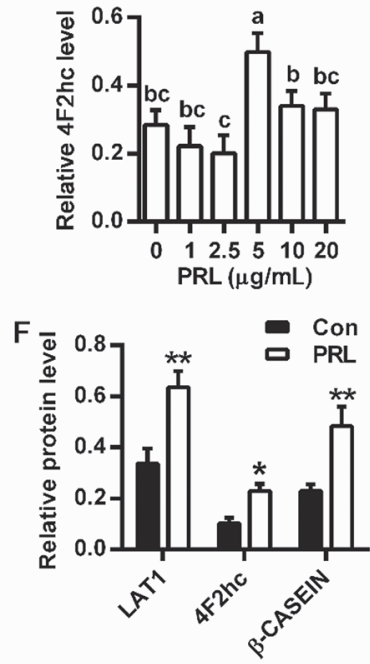

G

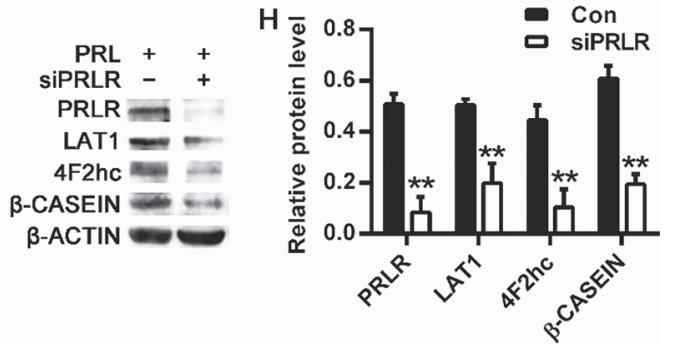

Figure 1. Prolactin (PRL) regulates LAT1 (L-type amino acid transporter 1 ) and $\beta$-casein expression in mammary epithelial cells of dairy cows. (A) Relative mRNA expression of LAT1 in mammary epithelial cells cultured with increasing concentration of PRL. (B) Western blot analysis of LAT1 and 4F2he (heavy chain of 4F2) expression in mammary epithelial cells cultured with increasing concentrations of PRL. (C) Quantification of LAT1 expression from the Western blots in panel B. (D) Quantification of $4 \mathrm{~F} 2 \mathrm{hc}$ expression from the Western blots in panel B. For A and B, mammary epithelial cells were incubated with $1,2.5,5,10$, and $20 \mu \mathrm{g} / \mathrm{mL}$ PRL for $24 \mathrm{~h}$. The cells were harvested for real-time quantitative (q)PCR and Western blot analyses. (E) Effects of PRL on LAT1, 4F2hc, and $\beta$-casein expression in dairy cow mammary epithelial cells. (F) Quantification of LAT1, $4 \mathrm{~F} 2 \mathrm{hc}$, and $\beta$-casein expression from the Western blots in panel E. For E, mammary epithelial cells were incubated with $5 \mu \mathrm{g} / \mathrm{mL}$ PRL for 24 h. Cells cultured in medium without PRL were used as control (labeled Con in panel F). (G) Effects of PRL receptor $(P R L R)$ knockdown on PRL-stimulated LAT1, 4F2hc, and $\beta$-casein expression in mammary epithelial cells of dairy cows. (H) Quantification of LAT1, 4F2hc, and $\beta$-casein expression from the Western blots in panel G. For G, mammary epithelial cells were transfected with PRLR short interfering (si) RNA or scrambled siRNA (labeled siPRLR - in panel G; labeled Con in panel $\mathrm{H}$ ). Data are presented as the mean \pm SEM of 3 independent experiments. For A, C, and D, means without a common letter (a-d) differ at $P<0.05$. For $\mathrm{F}$ and $\mathrm{H},{ }^{*} P<0.05$; ${ }^{* *} P<0.01$.

signaling, mammary epithelial cells were cultured in medium with $5 \mu \mathrm{g} / \mathrm{mL}$ PRL for $24 \mathrm{~h}$. Compared with control, the abundance of LAT1, $4 \mathrm{~F} 2 \mathrm{hc}$, and $\beta$-casein protein increased significantly (Figure 1E, F; $P<0.05$, $P<0.01)$. We then transfected mammary epithelial cells with $P R L R$ siRNA in the presence of $5 \mu \mathrm{g} / \mathrm{mL}$ PRL. Western blot results showed that PRLR siRNA abolished the stimulatory actions of PRL on LAT1, $4 \mathrm{~F} 2 \mathrm{hc}$, and $\beta$-casein expression (Figure 1G, H; P< 0.01), indicating that PRL signaling can regulate LAT1 expression and milk protein synthesis in mammary epithelial cells of dairy cows.

\section{PRL Regulates Milk Protein Synthesis via LAT1}

Mammary epithelial cells were treated with $5 \mu \mathrm{g} / \mathrm{mL}$ PRL in the presence or absence of $\mathrm{BCH}$, a competitive inhibitor of LAT1. As shown in Figure 2A, the addition of BCH significantly inhibited PRL-induced LAT1 expression $(P<0.01)$, which in turn decreased $\beta$-casein synthesis $(P<0.01)$. Next, we transfected mammary epithelial cells with LAT1 siRNA; LAT1 siRNA knockdown significantly decreased LAT1 expression compared with control (scrambled) siRNA (Figure $2 \mathrm{C}, \mathrm{D} ; P<$ 0.01 ). The expression of $\beta$-casein was also decreased in the PRL + LAT1 knockdown group compared with the $\mathrm{PRL}+$ scrambled siRNA group (Figure $2 \mathrm{C}, \mathrm{D} ; \mathrm{P}<$ $0.01)$.

\section{PRL Induces LAT1 Expression by Activating STAT5}

To investigate whether PRLR-STAT5 signaling is involved in PRL-induced LAT1 expression, mammary epithelial cells were cultured in medium with $5 \mu \mathrm{g} / \mathrm{mL}$ PRL for $24 \mathrm{~h}$. Compared with the control, treatment of mammary epithelial cells with $5 \mu \mathrm{g} / \mathrm{mL}$ PRL significantly increased the expression of PRLR, STAT5, and p-STAT5, as well as the expression of LAT1 and 4 F2hc (Figure 3A, B; $P<0.01$ ). Next, we transfected mammary epithelial cells with $P R L R$ siRNA in the presence of PRL. Compared with a scrambled control siRNA, $P R L R$ siRNA significantly decreased the expression of STAT5 and p-STAT5 (Figure 3C, D; $P<0.01$ ). The expression of LAT1 and 4F2hc also decreased significantly (Figure 3C, D; $P<0.01$ ). Then, we transfected mammary epithelial cells with STAT5 siRNA in the presence of PRL. At $24 \mathrm{~h}$ after transfection, we observed a significant decrease in STAT5 expression in the STAT5 siRNA-treated group compared with the control scrambled siRNA group. The STAT5 siRNA knockdown inhibited the stimulatory effects of PRL on STAT5 activation and LAT1/4F2hc expression (Figure $3 \mathrm{E}, \mathrm{F} ; P<0.01)$. 
A

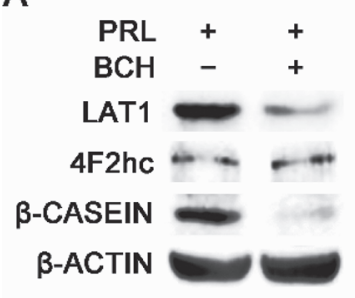

C

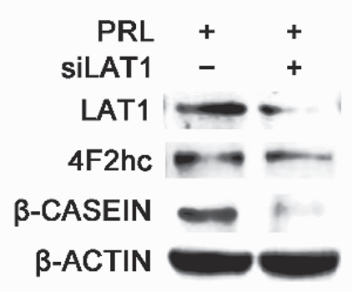

B

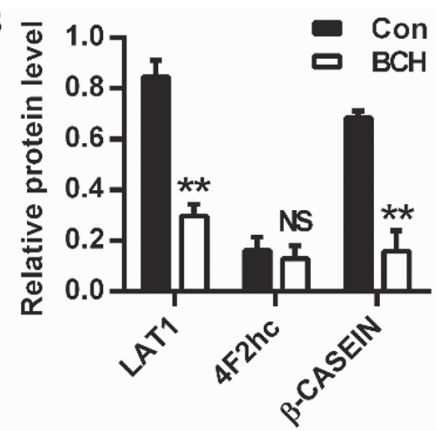

D

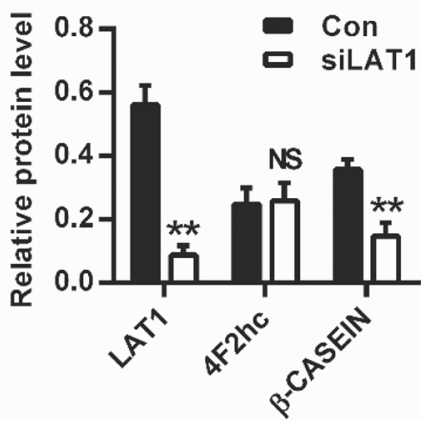

Figure 2. Effect of LAT1 (L-type amino acid transporter 1) inhibition on prolactin (PRL)-stimulated $\beta$-casein expression in mammary epithelial cells of dairy cows. (A) Western blot analysis of PRLstimulated $\beta$-casein expression in 2-amino-2-norbornanecarboxylic acid (BCH)-treated mammary epithelial cells of dairy cows. Mammary epithelial cells were cultured in medium with $5 \mu \mathrm{g} / \mathrm{mL}$ PRL in the presence or absence of $\mathrm{BCH}$. The cells were then harvested for determination of LAT1, 4F2hc (heavy chain of $4 \mathrm{~F} 2$ ), and $\beta$-casein expression. (B) Quantification of LAT1, 4F2hc, and $\beta$-casein expression from the Western blots in panel A. Cells cultured in medium without $\mathrm{BCH}$ were used as control (labeled Con in panel B). (C) Western blot analysis of PRL-stimulated $\beta$-casein expression in LAT1 knockdown mammary epithelial cells of dairy cows. Mammary epithelial cells were transfected with LAT1 short interfering (si)RNA or scrambled siRNA (labeled siLAT1 - in panel C) for $24 \mathrm{~h}$ in the presence of $5 \mu \mathrm{g} /$ $\mathrm{mL}$ PRL. The cells were then harvested for determination of LAT1, $4 \mathrm{~F} 2 \mathrm{hc}$, and $\beta$-casein expression. (D) Quantification of LAT1, 4F2hc, and $\beta$-casein expression from the Western blots in panel C. Cells transfected with scrambled siRNA were used as control (labeled Con in panel D). Data are presented as the mean \pm SEM of 3 independent experiments; ${ }^{* *} P<0.01$

\section{PRL Promotes Cell Surface Recruitment of LAT1 from the Intracellular Compartment}

To investigate changes in cell surface LAT1 expression, we isolated plasma membranes from cultured mammary epithelial cells and determined LAT1 expression in response to $5 \mu \mathrm{g} / \mathrm{mL}$ PRL stimulation. We observed that PRL stimulation caused a marked increase in the expression of LAT1 in the plasma membrane compared with control (Figure 4A, B; $P<0.01$ ), whereas the expression of LAT1 in the cytosol was significantly decreased in the PRL-treated group compared with the control group (Figure 4C, D; $P<0.01$ ).
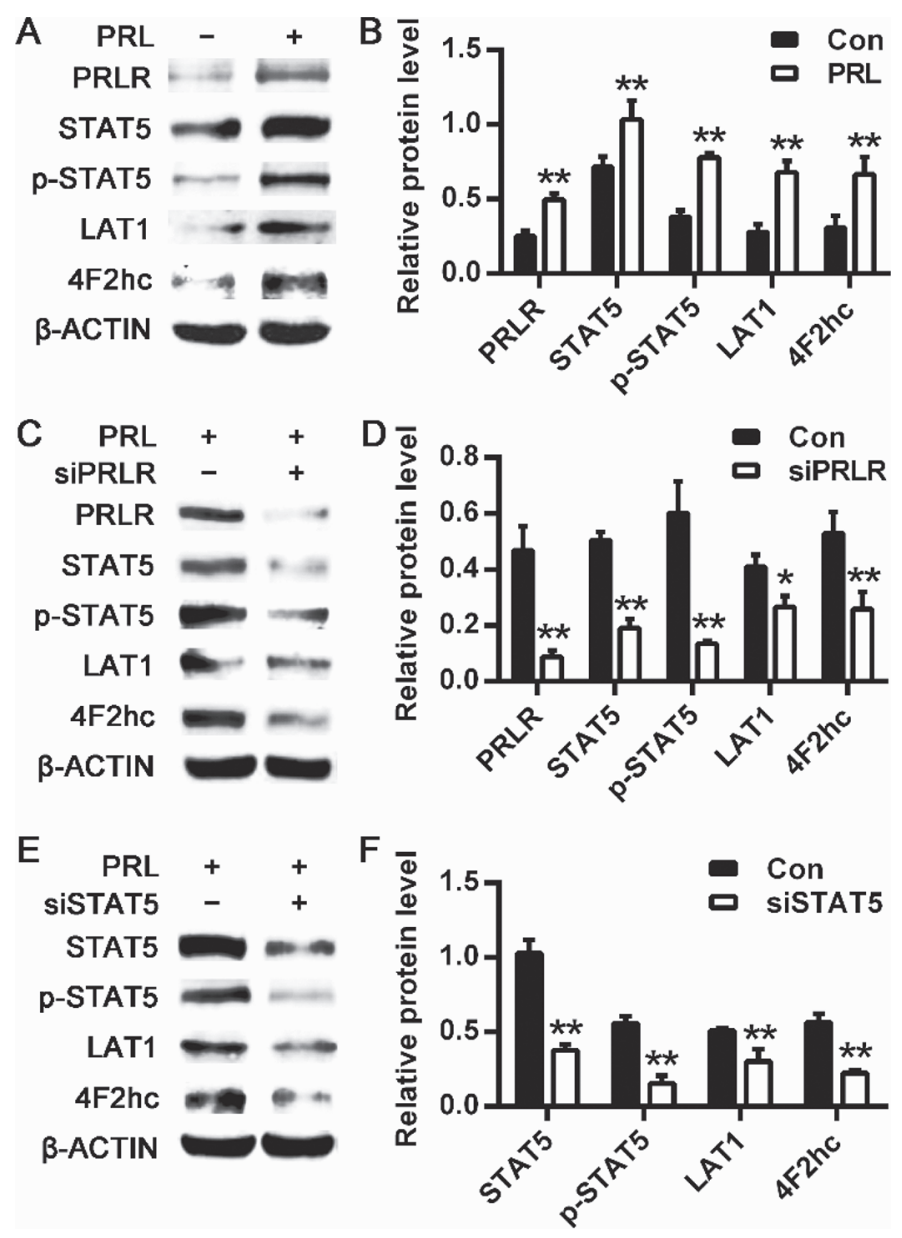

Figure 3. Effect of the prolactin (PRL) signaling pathway on LAT1 (L-type amino acid transporter 1) expression in mammary epithelial cells of dairy cows. (A) Western blot analysis of PRL signaling molecules and LAT1 expression in mammary epithelial cells of dairy cows. Mammary epithelial cells were cultured in medium with $5 \mu \mathrm{g} /$ $\mathrm{mL}$ PRL for $24 \mathrm{~h}$. The cells were harvested for determination of PRL receptor (PRLR), signal transducer and activator of transcription 5 (STAT5), phosphorylated (p)-STAT5, LAT1, and 4F2hc (heavy chain of 4F2) expression. (B) Quantification of PRL signaling molecules, LAT1, and 4F2hc expression from the Western blots in panel A. Cells cultured in medium without PRL were used as control (labeled Con in panel B). (C) Western blot analysis of PRL signaling molecules and LAT1 expression in PRLR knockdown mammary epithelial cells of dairy cows. (D) Quantification of PRL signaling molecules, LAT1, and $4 \mathrm{~F} 2 \mathrm{hc}$ expression from the Western blots in panel C. Cells transfected with scrambled siRNA were used as control (labeled Con in panel D). (E) Western blot analysis of PRL signaling molecules and LAT1 expression in STAT5 knockdown mammary epithelial cells of dairy cows. (F) Quantification of PRL signaling molecules, LAT1, and $4 \mathrm{~F} 2 \mathrm{hc}$ expression from the Western blots in panel E. Cells transfected with scrambled siRNA were used as control (labeled Con in panel F). For $\mathrm{C}$ and E, mammary epithelial cells were transfected with $P R L R$ (labeled siPRLR+ in panel C) or STAT5 (labeled siSTAT5+ in panel E) short interfering (si)RNA for $24 \mathrm{~h}$ in the presence of $5 \mu \mathrm{g} / \mathrm{mL}$ PRL before harvest. Data are presented as the mean \pm SEM of 3 independent experiments. ${ }^{*} P<0.05 ;{ }^{*} P<0.01$. 


\section{DISCUSSION}

During lactation, the mammary gland requires active uptake of AA to support milk synthesis (Manjarin et al., 2014); LAT1 is an indispensable transporter of EAA (Hyde et al., 2003). In mammary tissues of lactating cows, LAT1 is highly expressed on the plasma membrane of alveolar epithelial cells, suggesting its roles in providing EAA to the mammary gland (Lin et al., 2018).

Prolactin is known to be mammogenic and lactogenic in both monogastric and ruminant mammals (Lacasse et al., 2016). The actions of PRL on AA uptake by mammary tissues have been described in rodents. In rat mammary gland, PRL has an important role in the regulation of AA uptake (Viña et al., 1981). The sodiumcoupled neutral amino acid transporter 2 (SNAT2) is characterized as a classical system A transporter and is important for the uptake of small neutral AA into the mammary gland to promote cell proliferation during gestation and to induce milk protein synthesis during lactation (Velázquez-Villegas et al., 2014). Studies in mammary gland explants from lactating rats have demonstrated that PRL treatment increases SNAT2 mRNA and protein abundance (Velázquez-Villegas et

A

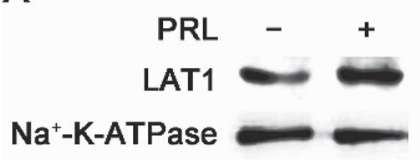

B

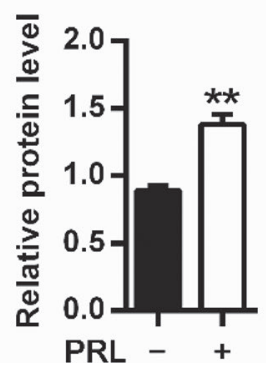

Figure 4. Effect of prolactin (PRL) on plasma membrane expression of LAT1 (L-type amino acid transporter 1) in mammary epithelial cells of dairy cows. (A) Western blot showing the expression of LAT1 in isolated plasma membranes of mammary epithelial cells. Cells were cultured in medium with $5 \mu \mathrm{g} / \mathrm{mL}$ PRL for $24 \mathrm{~h}$. The plasma membrane fraction was then isolated for Western blot analysis; $\mathrm{Na}^{+}$K-ATPase served as a loading control. (B) Quantification of LAT1 expression from the Western blots in panel A. (C) Western blot showing the expression of LAT1 in the cytosol of mammary epithelial cells. Cells were cultured in medium with $5 \mu \mathrm{g} / \mathrm{mL}$ PRL for $24 \mathrm{~h}$. The cytosol was isolated for Western blot analysis. $\beta$-Actin served as a loading control. (D) Quantification of LAT1 expression from the Western blots in panel C. Data are presented as the mean \pm SEM of 3 independent experiments. $* * P<0.01$. al., 2015). In the current study, we found that mRNA levels of LAT1 in cultured mammary epithelial cells of dairy cows were increased with increasing concentrations of PRL and peaked at $5 \mu \mathrm{g} / \mathrm{mL}$ PRL. The expression profile of LAT1 under different PRL concentrations was similar to that of LAT1 mRNA, suggesting that PRL regulates LAT1 expression at least at the transcriptional level in mammary gland of dairy cow. Prolactin signaling begins with its binding to the long isoform of PRLR (Lesueur et al., 1991; Cassy et al., 1998). Knockdown of PRLR in cultured mammary epithelial cells of dairy cows decreased LAT1 and $4 \mathrm{~F} 2 \mathrm{hc}$ expression, demonstrating that PRL signaling could directly regulate $L A T 1$ expression in mammary epithelial cells of dairy cows.

Previous studies have demonstrated that PRL can increase milk protein gene expression and secretion in rodents and that suppression of PRL inhibits lactation (Taylor and Peaker, 1975; Guyette et al., 1979; Flint and Vernon, 1998). However, PRL has not always been considered a galactopoietic hormone in ruminants, because the effect of inhibiting PRL function on milk production in dairy cows is less obvious (Karg et al., 1972; Smith et al., 1974). Moreover, Plaut et al. (1987) observed that injecting dairy cows in early lactation with recombinant PRL at $120 \mathrm{mg} / \mathrm{d}$ for 14 d did not significantly affect milk yield. Although the involvement of PRL in the control of ruminant lactation has been controversial, more recent studies have provided good evidence that PRL is also galactopoietic in dairy cows (Lacasse et al., 2016). Experiments in vivo showed that inhibition of PRL with quinagolide decreased milk production in dairy cows (Lacasse et al., 2011), whereas increasing the PRL concentration by administering a dopamine antagonist increased milk production (Lacasse and Ollier, 2015). Experiments in vitro have also demonstrated that PRL is galactopoietic in dairy cows. In mammary explants of dairy cows, PRL induces the synthesis and release of $\alpha$-lactalbumin (Goodman et al., 1983). In cultured bovine mammary epithelial cells, Choi et al. (1988) reported that PRL stimulation, even in the absence of insulin and hydrocortisone, is capable of increasing milk protein mRNA abundance. We also observed upregulated $\beta$-casein expression in PRL-treated mammary epithelial cells of dairy cows compared with control cells. Milk protein synthesis requires a steady and sufficient supply of AA (Bequette et al., 1998). Because LAT1 is highly expressed in lactating mammary tissues of dairy cows and is capable of transporting large neutral AA, including the branched-chain AA, the expression and activity of LAT1 likely influence PRL signaling and function. As anticipated, LAT1 inhibitor and gene knockdown in the current study both suppressed PRL-induced $\beta$-casein 
expression in cultured mammary epithelial cells of dairy cows, indicating that PRL signaling-induced milk protein synthesis is dependent on LAT1.

Signal transducer and activator of transcription 5 was originally identified in the lactating mammary gland and is the primary transcription factor responsible for PRL signaling (Kabotyanski et al., 2006). Prolactin signaling induces PRLR dimerization and activation of JAK2 kinase, which in turn activates STAT5 by phosphorylating this molecule (Bole-Feysot et al., 1998). Once activated, STAT5 translocates to the nucleus and binds to specific regulatory sequences in the promoters of target genes such as milk protein genes (Groner and Gouilleux, 1995). In mouse HC11 cells, PRL stimulation results in a rapid recruitment of p-STAT5 to the CSN2 promoter and enhancer, which in turn regulates CSN2 gene expression (Kabotyanski et al., 2006). However, it had been unclear whether PRL regulates LAT1 expression in bovine mammary epithelial cells via STAT5 activation. In the current study, we showed that the addition of PRL led to a robust increase in STAT5 activity, as shown by the phosphorylation of STAT5 on Tyr694, whereas knockdown of PRLR or STAT5 significantly inhibited PRL-stimulated STAT5 phosphorylation and further decreased LAT1 expression. These results provide good evidence that PRL signaling regulates LAT1 expression by activating PRLR-STAT5 signaling. We also found a putative STAT5 response element in the bovine LAT1 gene promoter (data not shown), which further supports our current hypothesis that PRL regulates LAT1 expression by activating STAT5 signaling.

Here, we showed that PRL upregulates LAT1 expression and activity by facilitating the translocation of LAT1 from the cytosol to the plasma membrane in mammary epithelial cells of dairy cows. The regulation of trafficking of nutrient transporters between intracellular pools and the plasma membrane is a well-established mechanism by which cellular nutrient uptake is modified. With regard to AA transporters, the trafficking of the AA transport system $\mathrm{A}$ isoform SNAT2 in insulin-stimulated skeletal muscle cells and 3T3-L1 adipocytes has been studied (Hyde et al., 2002; Hatanaka et al., 2006). In primary human trophoblast cells, mTOR (mammalian target of rapamycin) signaling regulates LAT1 activity by influencing the trafficking of this transporter isoform to the plasma membrane (Rosario et al., 2013). In the present study, we observed that PRL induced an increase in the plasma membrane abundance of LAT1 in mammary epithelial cells of dairy cows. These findings indicate that the expression of LAT1 in cultured bovine mammary epithelial cells may be regulated not just at the transcriptional level; our results provide a possible mechanism for PRL regulation of LAT1 activity at the posttranslational level.

\section{CONCLUSIONS}

Prolactin signaling may increase milk protein synthesis by regulating LAT1 expression in mammary epithelial cells of dairy cows. Treatment of bovine mammary epithelial cells with PRL increases movement of LAT1 from an intracellular pool to the membrane, indicating an increase in LAT1 transport activity in lactating mammary tissues of dairy cows.

\section{ACKNOWLEDGMENTS}

This work was supported by grants from the National Natural Science Foundation of China (31771453 to Y. L., and 31671285 to X. H.), the Open Research Fund for Key Laboratory of Dairy Science (Northeast Agricultural University), Ministry of Education, Heilongjiang Province, China (KLDS-18-008), and the "Academic Backbone" Project of Northeast Agricultural University (18XG25, China). No competing financial interests exist.

\section{REFERENCES}

Bequette, B. J., F. R. Backwell, and L. A. Crompton. 1998. Current concepts of amino acid and protein metabolism in the mammary gland of the lactating ruminant. J. Dairy Sci. 81:2540-2559. https: //doi.org/10.3168/jds.S0022-0302(98)70147-X.

Boado, R. J., J. Y. Li, M. Nagaya, C. Zhang, and W. M. Pardridge. 1999. Selective expression of the large neutral amino acid transporter at the blood-brain barrier. Proc. Natl. Acad. Sci. USA 96:12079-12084. https://doi.org/10.1073/pnas.96.21.12079.

Bole-Feysot, C., V. Goffin, M. Edery, N. Binart, and P. A. Kelly. 1998. Prolactin (PRL) and its receptor: Actions, signal transduction pathways and phenotypes observed in PRL receptor knockout mice. Endocr. Rev. 19:225-268. https://doi.org/10.1210/edrv.19.3 .0334 .

Cassy, S., M. Charlier, L. Belair, M. Guillomot, G. Charron, B. Bloch, and J. Djiane. 1998. Developmental expression and localization of the prolactin receptor (PRL-R) gene in ewe mammary gland during pregnancy and lactation: Estimation of the ratio of the two forms of PRL-R messenger ribonucleic acid. Biol. Reprod. 58:1290-1296. https://doi.org/10.1095/biolreprod58.5.1290.

Choi, Y. J., W. L. Keller, I. E. Berg, C. S. Park, and A. G. Mackinlay. 1988. Casein gene expression in bovine mammary gland. J. Dairy Sci. 71:2898-2903. https://doi.org/10.3168/jds.S0022 -0302(88)79887-2.

Christensen, H. N. 1990. Role of amino acid transport and countertransport in nutrition and metabolism. Physiol. Rev. 70:43-77. https://doi.org/10.1152/physrev.1990.70.1.43.

Drummond, M. J., E. L. Glynn, C. S. Fry, K. L. Timmerman, E. Volpi, and B. B. Rasmussen. 2010. An increase in essential amino acid availability upregulates amino acid transporter expression in human skeletal muscle. Am. J. Physiol. Endocrinol. Metab. 298:E1011-E1018. https://doi.org/10.1152/ajpendo.00690.2009.

Edgerton, L. A., and H. D. Hafs. 1973. Serum luteinizing hormone, prolactin, glucocorticoid, and progestin in dairy cows from calving to gestation. J. Dairy Sci. 56:451-458. https://doi.org/10.3168/jds .S0022-0302(73)85199-9.

Finucane, K. A., T. B. McFadden, J. P. Bond, J. J. Kennelly, and F Q. Zhao. 2008. Onset of lactation in the bovine mammary gland: Gene expression profiling indicates a strong inhibition of gene expression in cell proliferation. Funct. Integr. Genomics 8:251-264. https://doi.org/10.1007/s10142-008-0074-y. 
Flint, D. J., and R. G. Vernon. 1998. Effects of food restriction on the responses of the mammary gland and adipose tissue to prolactin and growth hormone in the lactating rat. J. Endocrinol. 156:299305. https://doi.org/10.1677/joe.0.1560299.

Goodman, G. T., R. M. Akers, K. H. Friderici, and H. A. Tucker. 1983. Hormonal regulation of alpha-lactalbumin secretion from bovine mammary tissue cultured in vitro. Endocrinology 112:1324-1330. https://doi.org/10.1210/endo-112-4-1324.

Groner, B., and F. Gouilleux. 1995. Prolactin-mediated gene activation in mammary epithelial cells. Curr. Opin. Genet. Dev. 5:587594. https://doi.org/10.1016/0959-437X(95)80027-1.

Guyette, W. A., R. J. Matusik, and J. M. Rosen. 1979. Prolactinmediated transcriptional and post-transcriptional control of casein gene expression. Cell 17:1013-1023. https://doi.org/10.1016/0092 -8674(79)90340-4.

Hatanaka, T., Y. Hatanaka, J. Tsuchida, V. Ganapathy, and M. Setou. 2006. Amino acid transporter ATA2 is stored at the trans-Golgi network and released by insulin stimulus in adipocytes. J. Biol. Chem. 281:39273-39284. https://doi.org/10.1074/jbc.M604534200.

Hyde, R., K. Peyrollier, and H. S. Hundal. 2002. Insulin promotes the cell surface recruitment of the SAT2/ATA2 system A amino acid transporter from an endosomal compartment in skeletal muscle cells. J. Biol. Chem. 277:13628-13634. https://doi.org/10.1074/jbc .M108609200.

Hyde, R., P. M. Taylor, and H. S. Hundal. 2003. Amino acid transporters: Roles in amino acid sensing and signalling in animal cells. Biochem. J. 373:1-18. https://doi.org/10.1042/bj20030405.

Kabotyanski, E. B., M. Huetter, W. Xian, M. Rijnkels, and J. M. Rosen. 2006. Integration of prolactin and glucocorticoid signaling at the beta-casein promoter and enhancer by ordered recruitment of specific transcription factors and chromatin modifiers. Mol. Endocrinol. 20:2355-2368. https://doi.org/10.1210/me.2006-0160.

Karg, H., D. Schams, and V. Reinhardt. 1972. Effects of 2-Br- $\alpha-$ ergocryptine on plasma prolactin level and milk yield in cows. Experientia 28:574-576. https://doi.org/10.1007/BF01931886.

Lacasse, P., V. Lollivier, R. M. Bruckmaier, Y. R. Boisclair, G. F. Wagner, and M. Boutinaud. 2011. Effect of the prolactin-release inhibitor quinagolide on lactating dairy cows. J. Dairy Sci. 94:1302-1309. https://doi.org/10.3168/jds.2010-3649.

Lacasse, P., and S. Ollier. 2015. The dopamine antagonist domperidone increases prolactin concentration and enhances milk production in dairy cows. J. Dairy Sci. 98:7856-7864. https://doi.org/10 $.3168 /$ jds.2015-9865.

Lacasse, P., S. Ollier, V. Lollivier, and M. Boutinaud. 2016. New insights into the importance of prolactin in dairy ruminants. J. Dairy Sci. 99:864-874. https://doi.org/10.3168/jds.2015-10035.

Lesueur, L., M. Edery, S. Ali, J. Paly, P. A. Kelly, and J. Djiane. 1991. Comparison of long and short forms of the prolactin receptor on prolactin-induced milk protein gene transcription. Proc. Natl. Acad. Sci. USA 88:824-828. https://doi.org/10.1073/pnas .88.3.824

Lin, Y., X. Duan, H. Lv, Y. Yang, Y. Liu, X. Gao, and X. Hou. 2018. The effects of L-type amino acid transporter 1 on milk protein synthesis in mammary glands of dairy cows. J. Dairy Sci. 101:16871696. https://doi.org/10.3168/jds.2017-13201.

Lollivier, V., P. Lacasse, J. Angulo Arizala, P. Lamberton, S. Wiart, J. Portanguen, R. Bruckmaier, and M. Boutinaud. 2015. In vivo inhibition followed by exogenous supplementation demonstrates galactopoietic effects of prolactin on mammary tissue and milk production in dairy cows. J. Dairy Sci. 98:8775-8787. https://doi .org/10.3168/jds.2015-9853.

Manjarin, R., B. J. Bequette, G. Wu, and N. L. Trottier. 2014. Linking our understanding of mammary gland metabolism to amino acid nutrition. Amino Acids 46:2447-2462. https://doi.org/10.1007/ s00726-014-1818-8.

Mastroberardino, L., B. Spindler, R. Pfeiffer, P. J. Skelly, J. Loffing, C. B. Shoemaker, and F. Verrey. 1998. Amino-acid transport by heterodimers of $4 \mathrm{~F} 2 \mathrm{hc} / \mathrm{CD} 98$ and members of a permease family. Nature 395:288-291. https://doi.org/10.1038/26246.
Nakamura, E., M. Sato, H. Yang, F. Miyagawa, M. Harasaki, K. Tomita, S. Matsuoka, A. Noma, K. Iwai, and N. Minato. 1999. 4F2 (CD98) heavy chain is associated covalently with an amino acid transporter and controls intracellular trafficking and membrane topology of 4F2 heterodimer. J. Biol. Chem. 274:3009-3016. https: //doi.org/10.1074/jbc.274.5.3009.

Napolitano, L., M. Scalise, M. Galluccio, L. Pochini, L. M. Albanese, and C. Indiveri. 2015. LAT1 is the transport competent unit of the LAT1/CD98 heterodimeric amino acid transporter. Int. J. Biochem. Cell Biol. 67:25-33. https://doi.org/10.1016/j.biocel.2015 .08 .004 .

Neville, M. C., T. B. McFadden, and I. Forsyth. 2002. Hormonal regulation of mammary differentiation and milk secretion. J. Mammary Gland Biol. Neoplasia 7:49-66. https://doi.org/10.1023/A: 1015770423167.

Plaut, K., D. E. Bauman, N. Agergaard, and R. M. Akers. 1987. Effect of exogenous prolactin administration on lactational performance of dairy cows. Domest. Anim. Endocrinol. 4:279-290. https://doi .org/10.1016/0739-7240(87)90024-5.

Rosario, F. J., Y. Kanai, T. L. Powell, and T. Jansson. 2013. Mammalian target of rapamycin signalling modulates amino acid uptake by regulating transporter cell surface abundance in primary human trophoblast cells. J. Physiol. 591:609-625. https://doi.org/10 .1113 /jphysiol.2012.238014.

Schmittgen, T. D., and K. J. Livak. 2008. Analyzing real-time PCR data by the comparative $\mathrm{C}(\mathrm{T})$ method. Nat. Protoc. 3:1101-1108. https://doi.org/10.1038/nprot.2008.73.

Smith, V. G., T. W. Beck, E. M. Convey, and H. A. Tucker. 1974. Bovine serum prolactin, growth hormone, cortisol and milk yield after ergocryptine. Neuroendocrinology 15:172-181. https://doi .org/10.1159/000122305.

Taylor, J. C., and M. Peaker. 1975. Effects of bromocriptine on milk secretion in the rabbit. J. Endocrinol. 67:313-314. https://doi.org/ 10.1677/joe.0.0670313.

Velázquez-Villegas, L. A., A. M. Lopez-Barradas, N. Torres, R. Hernandez-Pando, J. C. Leon-Contreras, O. Granados, V. Ortiz, and A. R. Tovar. 2015. Prolactin and the dietary protein/carbohydrate ratio regulate the expression of SNAT2 amino acid transporter in the mammary gland during lactation. Biochim. Biophys. Acta 1848:1157-1164. https://doi.org/10.1016/j.bbamem.2015.02.011.

Velázquez-Villegas, L. A., V. Ortiz, A. Strom, N. Torres, D. A. Engler, R. Matsunami, D. Ordaz-Rosado, R. Garcia-Becerra, A. M. Lopez-Barradas, F. Larrea, J. A. Gustafsson, and A. R. Tovar. 2014. Transcriptional regulation of the sodium-coupled neutral amino acid transporter (SNAT2) by 17beta-estradiol. Proc. Natl. Acad. Sci. USA 111:11443-11448. https://doi.org/10.1073/pnas .1412099111

Viña, J., I. R. Puertes, G. T. Saez, and J. R. Viña. 1981. Role of prolactin in amino acid uptake by the lactating mammary gland of the rat. FEBS Lett. 126:250-252. https://doi.org/10.1016/0014 $-5793(81) 80253-0$.

Yang, Y., Y. Lin, X. Duan, H. Lv, W. Xing, Q. Li, X. Gao, and X. Hou. 2017. The effects of cell death-inducing DNA fragmentation factor-alpha-like effector C (CIDEC) on milk lipid synthesis in mammary glands of dairy cows. J. Dairy Sci. 100:4014-4024. https://doi.org/10.3168/jds.2016-11549.

\section{ORCIDS}

Jinyu Zhou (৫) https://orcid.org/0000-0002-2268-2634

Minghui Jiang ๑ https://orcid.org/0000-0002-7755-5616

Ying Shi ๑ https://orcid.org/0000-0002-5195-204X

Shuyuan Song (®) https://orcid.org/0000-0003-2881-9029

Xiaoming Hou $\odot$ https://orcid.org/0000-0001-5908-3785

Ye Lin (1) https://orcid.org/0000-0002-9194-1441 